\title{
Hubungan Genetik antara Domba Wonosobo (Dombos), Domba Ekor Tipis (DET) dan Domba Batur (Dombat) Melalui Analisis Polimorfisme Protein Darah
}

\author{
F. Noviani, Sutopo dan E. Kurnianto \\ Program Studi Magister Ilmu Ternak, Program Pascasarjana \\ Fakultas Peternakan dan Pertanian, Universitas Diponegoro \\ Kampus Tembalang Semarang 50275
}

\begin{abstract}
ABSTRAK
Penelitian ini bertujuan untuk mengevaluasi hubungan genetik domba Wonosobo (Dombos), Domba Ekor Tipis (DET) dan Domba Batur (Dombat) melalui analisis polimorfisme protein darah menggunakan metode elektroforesis Polyacrylamid Gel Electrophoresis-Thin Layer Electrophoresis (PAGE-TLE). Sampel yang digunakan adalah darah dari 20 ekor Dombos (Kecamatan Kejajar, Kabupaten Wonosobo), 20 ekor DET (Kecamatan Gunung Pati, Kota Semarang) dan 20 ekor Dombat (Kecamatan Batur, Kabupaten Banjarnegara). Enam lokus protein plasma darah, yaitu pre-albumin $(\mathrm{Pa})$, albumin $(A l b)$, ceruloplasmin $(C p)$, transferrin $(T f)$, post-transferrin $(P-t f)$ dan amylase-I $(A m-I)$ diamati, selanjutnya dihitung frekuensi gen, heterosigositas individual, rataan heterosigositas dan jarak genetik antara tiga bangsa domba. Hasil penelitian menunjukkan bahwa lokus pre-albumin $(\mathrm{Pa})$, albumin $(A l b)$, ceruloplasmin $(C p)$, transferrin $(T f)$, post-transferrin $(P-t f)$ dan amylase-I $(A m-I)$, pada DET, Dombos dan Dombat bersifat polimorfik $(0,380-0,454)$. Hasil penelitian disimpulkan bahwa DET dan Dombat memiliki hubungan genetik yang lebih dekat dibandingkan antara DET-Dombos dan Dombos-Dombat.
\end{abstract}

Kata kunci: domba, polimorfisme, hubungan genetik, protein plasma darah

\section{Genetic Relationships among Wonosobo Sheep (Dombos), Thin-Tailed Sheep (DET) and Batur Sheep (Dombat) Based on Polymorphism Blood Protein Analysis}

\begin{abstract}
The objective of this study was to evaluate the genetic relationships among Wonosobo sheep (Dombos), Thin-Tailed sheep (DET) and Batur sheep (Dombat) through blood protein polymorphism analysis by using electrophoresis Polyacrylamid Gel Electrophoresis-Thin Layer Electrophoresis (PAGE-TLE). The blood of the 20 head of Dombos (Wonosobo regency), 20 head of DET (Semarang regency) and 20 head of Dombat (Banjarnegara regency) were used as materials. Six locus of blood plasma protein were observed, then the gene frequency, individual heterosigosity, average heterosigosity and genetic distance among three breed were calculated. The results showed that the locus of pre-albumin (Pa), albumin (Alb), ceruloplasmin (Cp), transferrin (Tf), post-transferrin (P-tf) and amylase-I (Am-I), at DET, Dombos and Dombat were polymorphic $(0,380-0,454)$. In conclusion, the DET and Dombat indicated the closer genetic relationship compared to DET-Dombos and Dombos-Dombat.
\end{abstract}

Key words: sheep, polymorphism, genetic relationship 


\section{PENDAHULUAN}

Pelestarian sumberdaya genetik ternak lokal merupakan bagian dari komponen keanekaragaman hayati penting untuk memenuhi kebutuhan protein hewani, pertanian dan perkembangan sosial masyarakat di masa yang akan datang. Salah satu keanekaragaman plasma nutfah yang dimiliki Jawa Tengah adalah domba lokal yang memiliki potensi untuk dikembangkan sebagai pemenuhan protein hewani masyarakat Indonesia seperti domba Ekor Tipis, domba Batur dan domba Wonosobo. Domba lokal tersebut memiliki potensi unggul yaitu produktivitas daging cukup baik, relatif tahan terhadap penyakit, mampu beradaptasi terhadap kondisi lingkungan yang buruk, dapat dijadikan sebagai daya tarik pariwisata daerah, keunggulan komparatif terutama dalam hal performa dan sifat prolifik untuk dikembangbiakan (Dinas Peternakan Kabupaten Wonosobo, 2007).

Deteksi polimorfisme biokimia dapat dilakukan dengan teknik gel elektroforesis Polyacrylamid Gel Electrophoresis-Thin Layer Electrophoresis (PAGE-TLE). Jenisjenis protein di dalam darah dapat menunjukkan polimorfisme dengan menggunakan prosedur elektroforesis yang merupakan cerminan perbedaan genetis. Polimorfisme biokemis yang diatur secara genetis sangat berguna untuk membantu penentuan asal-usul, menyusun hubungan filogenetis antara spesies dan bangsa-bangsa atau kelompok-kelompok dalam spesies dan kebanyakan dari polimorfisme protein darah diatur secara genetis oleh pasangan alel atau rangkaian alel tanpa dominansi (Warwick et al., 1990). Proporsi lokus pada alel yang ditempati oleh gen khusus memiliki ukuran kasar material untuk memperkirakan hubungan genetik diantara populasi.

Polimorfisme protein dapat diidentifikasi melalui teknik elektroforesis dengan membaca pita-pita yang muncul sesuai berat molekul dan zat kimia yang terkandung (Warwick et al.,1990). Polimorfisme protein telah digunakan untuk mengetahui hubungan genetik ternak, seperti yang dilakukan pada sapi (Sutopo et al., 2001; Winaya, 2010), kuda (Nozawa et al., 1981), kambing (Katsumata et al., 1981), domba (Tsunoda et al., 1999; Sumantri et al., 2007), keledai (Khana, 1973) dan ayam kedu (Johari et al., 2008). Penelitian ini bertujuan untuk mengetahui hubungan genetik domba DET, Dombat dan Dombos melalui analisis polimorfisme protein darah menggunakan metode elektroforesis.

\section{MATERI DAN METODE}

\section{Lokasi Penelitian}

Penelitian ini dilaksanakan pada peternakan rakyat di Kecamatan KejajarKabupaten Wonosobo, Kecamatan BaturBanjarnegara dan Kecamatan Gunung PatiKota Semarang Jawa Tengah. Proses analisis darah dilakukan di Laboratorium Biokimia Fakultas Kedokteran Hewan Universitas Gadjah Mada Yogyakarta dan Laboratorium Ilmu Pemuliaan dan Reproduksi Ternak Universitas Diponegoro.

\section{Materi Penelitian}

Penelitian ini menggunakan 20 ekor domba Ekor Tipis (DET), 20 ekor domba Batur (Dombat) dan 20 ekor domba Wonosobo (Dombos). Bahan yang digunakan untuk pengambilan sampel darah adalah: anti koagulan (EDTA) dan alkohol $70 \%$. Bahan yang digunakan untuk running gel adalah akrilamid 1 g, Bis-akrilamid $0,0265 \mathrm{~g}$, Tris $\mathrm{pH}$ 8,8 2,5 ml, Sodium Dodesil Sulfat (SDS) 10\% 0,1 ml, Amonium persulfat $100 \mu \mathrm{l}$ yang dicampur dengan Temed $5 \mu \mathrm{l}$ yang dicampur dengan Aquades $7,4 \mathrm{ml}$ hingga homogen. Bahan untuk stacking gel antara lain 0,225 g akrilamid, 0,006 g Bis Akrilamid, 0,63 ml Tris pH 6,8, SDS 10\% (Sodium Dedochil Sulphate) 0,075 ml, Amonium Persulfat (APS) $50 \mu \mathrm{l}$, Temed $5 \mu \mathrm{l}$ dan Aquades 4,295 ml, kemudian dicampur. Bahan untuk staining (perwarnaan) terdiri dari : 0,5 g Amido black, $25 \mathrm{ml}$ Metanol $\left(\mathrm{CH}_{3} \mathrm{OH}\right), 5 \mathrm{ml}$ Asam asetat $\left(\mathrm{CH}_{3} \mathrm{COOH}\right)$ dan $22,5 \mathrm{ml}$ Aquades. 
Keempat bahan tersebut diaduk hingga homogen, kemudian disaring. Bahan untuk destaining (pencucian) adalah $50 \mathrm{ml}$ aquades, $40 \mathrm{ml}$ Methanol, 0,1 gram Commasie Blue dan $10 \mathrm{ml}$ Asam asetat dicampur dalam erlenmeyer, kemudian diaduk sampai homogen. Pada elektroda buffer digunakan Tris 2,8 gram, Glycine 14,4 gram, SDS $10 \%$ sebanyak $10 \mathrm{ml}$ dan aquades sampai volume mencapai $100 \mathrm{ml}$.

\section{Metode Penelitian}

Darah diambil dari vena juguralis sebanyak $5 \mathrm{ml}$ dengan menggunakan syringe. Sampel darah dimasukkan ke tabung vakum yang teleh berisi antikolagan EDTA. Selanjutnya disimpan dalam cooler bag. Sampel darah kemudian disentrifus selama 10 menit dengan kecepatan 3500 rpm pada suhu $10^{\circ} \mathrm{C}$. Setelah disentrifus, sampel darah terpisahkan antara plasma darah dan sel darah. Masing-masing bagian tersebut dipisahkan dan dimasukkan ke minitube dan disimpan dalam freezer pada suhu $-20^{\circ} \mathrm{C}$, sebelum digunakan untuk proses elektroforesis.

Larutan running gel yang lebih dulu telah disiapkan kemudian dimasukkan pada plate gel dengan ukuran 10 × $8 \mathrm{~cm}$. Larutan tersebut dimasukkan pada sela-sela plate gel, yang kedua tepinya telah ditutup karet dan alat penjepit agar larutan tidak merembes keluar. Setelah larutan running gel padat, dilanjutkan dengan memasukkan larutan stacking gel ke dalam plate yang sama. Sebelum mengeras, dimasukkan sisir yang terbuat dari mika ke dalam sela-sela rongga. Setelah mengeras kemudian sisir diambil sehingga akan terbentuk lubang-lubang yang akan berfungsi sebagai tempat meletakkan sampel. Tahap selanjutnya adalah proses elektroforesis yang didahului dengan memasukkan elektroda $\mathrm{pH}$ selama proses elektroforesis. Setelah larutan dimasukkan, proses elektroforesis dijalankan dengan menggunakan voltase 125 volt dan arus konstan $29 \mathrm{~mA}$, dengan waktu running selama 3 jam.
Setelah running selesai, slab dibuka untuk memisahkan gel dari lempeng kaca, kemudian gel diberi pewarna Coomasie brilliant blue pada baki plastik, dibiarkan selama 15 menit. Proses yang terakhir dilakukan adalah pencucian gel. Gel yang telah diwarnai diberi larutan pencuci sambil digoyang-goyang dan larutan pencuci diganti beberapa kali sampai jernih dan terlihat pita-pita protein plasma darah. Langkah selanjutnya adalah membandingkan pita-pita yang muncul dengan pita-pita marker protein sehingga akan diketahui zona lokus yang dimaksudkan sehingga akan didapat berat molekul protein yang dikehendaki yaitu prealbumin $(P a)$, albumin $(A l b)$, cerruloplasmin $(C p)$, transferrin $(T f)$, post-transferrin $(P-t f)$ dan amylase-I $(A m-I)$.

\section{Analisis Data}

1. Frekuensi gen dihitung dengan menggunakan formula Warwick et al. (1990).

$\mathrm{F}_{\mathrm{An}}=\frac{\sum \text { LokusAn }}{\sum \text { LokusA }_{1}+\sum \text { LokusA }_{2}+\ldots . .+\sum \text { LokusA }_{n}}$

dimana $\mathrm{FAn}=$ Frekuensi gen $\mathrm{A}$ pada lokus ke-n

2. Keragaman genetik ditentukan menggunakan rumus heterosigositas individual (h) bedasarkan rumus dari Nei (1987) dan rataan heterosigositas $(\mathrm{H})$ berdasarkan rumus dari Nozawa et al. (1981) :

$$
\begin{aligned}
& \mathrm{h}=1-\sum q_{i}^{2} \\
& \mathrm{H}=\frac{\sum \mathrm{h}}{\mathrm{r}} \text { atau } 1-\overline{\sum_{i} q_{i}^{2}} \\
& q_{i}=\text { frekuensi gen ke-i } \\
& \mathrm{h}=\text { heterosigositas individual } \\
& r=\text { jumlah lokus yang diamati } \\
& \overline{\mathrm{H}}=\text { rataan heterosigositas }
\end{aligned}
$$


Data yang diperoleh dianalisis menggunakan program DISPAN (Ota, 1993) untuk menghitung jarak genetik.

\section{HASIL DAN PEMBAHASAN}

Hasil elektroforesis plasma darah domba dapat dilihat pada Gambar 1. Molekul-molekul sampel tersebut bergerak sesuai dengan berat molekul seperti yang ditunjukkan pada Gambar 1.

Karakteristik pre-albumin $(\mathrm{Pa})$, albumin (Alb), ceruloplasmin (Cp), transferrin (Tf), post-transferrin (P-tf) dan amylase-I $(A m-I)$ pada Dombos, DET dan Dombat bersifat polimorfik. Pita-pita yang terbentuk dapat diduga protein atau enzim yang dibawa oleh alel gen dalam lokus yang sama atau berbeda. Andersson et al. (1993) menyatakan studi polimorfisme dapat digunakan teknik elektroforesis sebagai proses analisisnya, dan eletroforesis tidak hanya digunakan untuk mendeteksi variasi alel dan gen dari suatu individu tetapi dapat menduga variasi genetik dalam populasi. Menurut Miler (2009), perbedaan bentuk setiap protein darah dapat dideteksi dengan membedakan kecepatan gerakannya dalam elektroforesis gel.

Lokus pre-albumin $(\mathrm{Pa})$ terletak di bagian atas lokus albumin (Alb) dan memiliki dua jenis alel yaitu $P a^{1}$ dan $P a^{2}$. Hasil penelitian Katsumata et al. (1981) bahwa kambing asli Indonesia ditemukan gen $P a^{1}$ dan $P a^{2}$. Lebih lanjut Nozawa et al. (1998) menjelaskan kambing Vietnam ditemukan adanya $\mathrm{Pa}^{1}$ dan $\mathrm{Pa}^{2}$. Perbandingan frekuensi gen $\mathrm{Pa}^{2}$ relatif lebih tinggi daripada frekuensi gen $\mathrm{Pa}^{1}$. Frekuensi gen alel $\mathrm{Pa}^{1}$ pada DET adalah 0,575 sedangkan Dombos adalah 0,375 dan Dombat yaitu 0,350. Frekuensi gen $P a^{2}$ pada Dombat lebih tinggi dibandingkan DET dan Dombos terlihat pada Tabel 1. Lokus albumin tampak lebih jelas dibandingkan lokus-lokus yang lain. Hal ini sesuai dengan Smithies (1955), bahwa plasma albumin memiliki porsi terbesar dan berat molekul 69 kDa sehingga menunjukkan pita-pita protein albumin lebih tebal. Pada penelitian ini diidentifikasi pada domba di Jawa Tengah terdapat dua alel yaitu $A l b^{B}$ dan $A l b^{C}$. Penelitian Tsunoda et al. (1999), domba Mongolia Tengah memiliki lokus albumin yang polimorfik dan dikontrol oleh dua alel yaitu $A l b^{C}$ dan $A l b^{x}$. Frekuensi gen tertinggi pada Dombos, DET maupun Dombat terdapat pada $A l b^{\mathrm{C}}$. Frekuensi gen $A l b^{B}$ pada Dombos, DET maupun Dombat masingmasing adalah 0,25; 0,15 dan 0,40. Lebih lanjut hasil penelitian ditunjukkan bahwa frekuensi gen $A l b^{C}$ pada Dombos, DET maupun Dombat masing-masing adalah 0,75; 0,85 dan 0,60. Pada domba Mongolia Tengah $A l b^{\mathrm{C}}$ memiliki frekuensi gen relatif lebih tinggi yaitu sebesar 0,989 dibandingkan dengan $A l b^{B}$ (Tsunoda et al., 1999).

Berdasarkan hasil analisis protein plasma darah dan interpretasi pita protein pada Dombos, DET dan Dombat pada lokus ceruloplasmin (Cp) bersifat polimorfik. Menurut Wyne et al. (1995), berat molekul protein ceruloplasmin (Cp) 70.000-75.000 dalton. Hasil identifikasi dan interprestasi gel elektroforesis ceruloplasmin (Cp) pada domba Wonosobo, domba Ekor Tipis dan domba Batur memiliki 2 alel yaitu $C p^{F}$ dan $C p^{S}$. Penelitian Hubbard (1999) menunjukkan bahwa pada kambing dan domba asli daerah Tibet ditemukan dua alel pada lokus ceruloplasmin, yaitu alel $C p^{F}$ dan $C p^{S}$. Hasil perhitungan frekuensi gen pada Tabel 2, menunjukkan bahwa alel $F$ pada Dombos adalah 0,675; DET 0,575 dan Dombat 0,375. Frekuensi gen alel S pada Dombat adalah 0,625; DET 0,425 dan Dombos 0,325. Hal ini berbeda dengan hasil penelitian yang dilakukan Wyne et al. (1995) pada domba hasil persilangan antara Domba Texel dengan Domba Suffolk di Finlandia bahwa frekuensi gen alel $C p^{S}$ lebih tinggi dibandingkan $C p^{F}$.

Lokus transferrin $(T f)$ pada domba Wonosobo, domba Ekor Tipis dan domba Batur memiliki karakter polimorfik. Penelitian Tsunoda et al. (1998) menyebutkan bahwa lokus tranferrin (Tf) pada domba-domba Vietnam memiliki karakter polimorfik. Hasil peneltian 

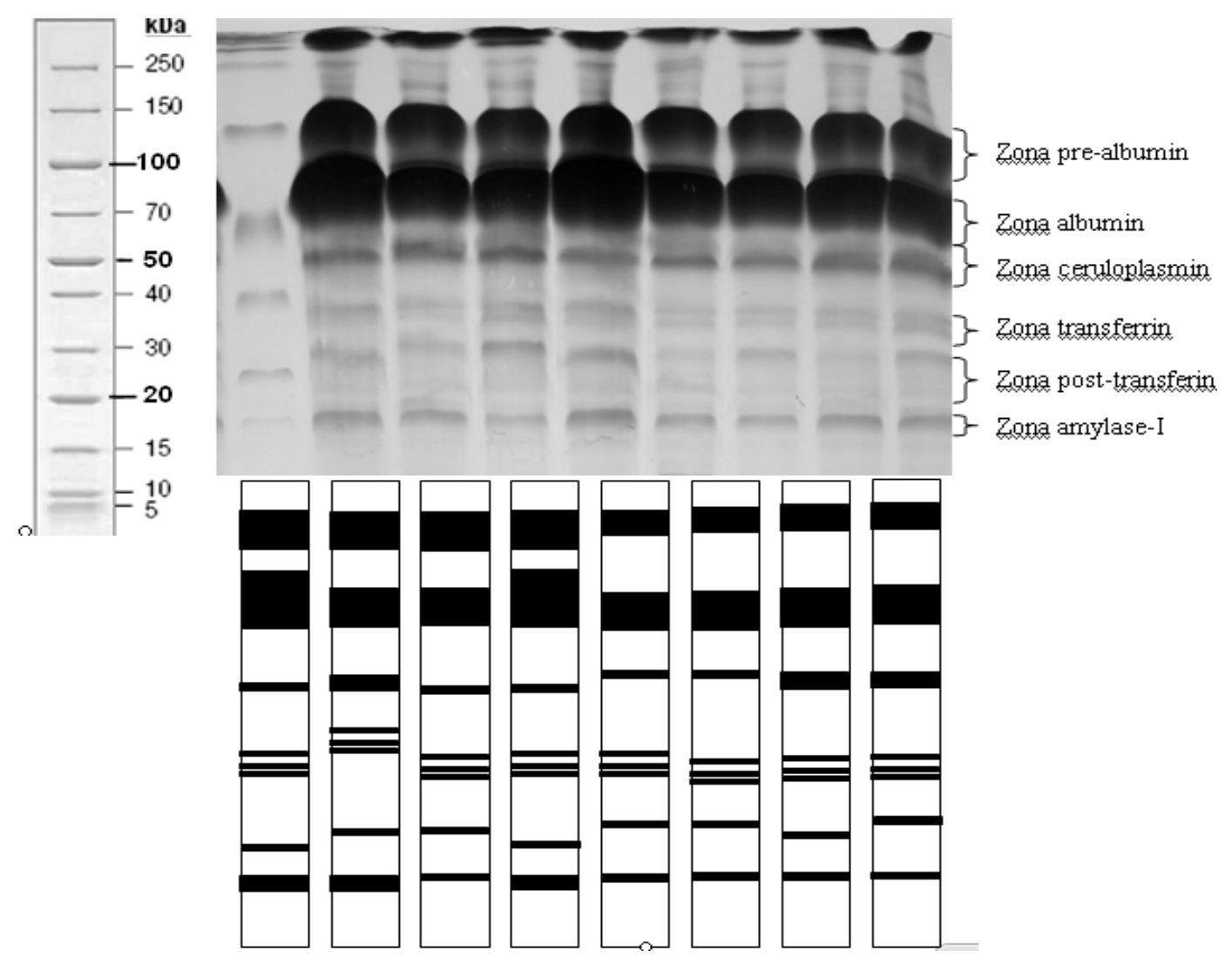

Gambar 1. Contoh pola pita protein dan skater plasma darah pada domba dengan marker fermentas

Tabel 1. Nilai frekuensi gen Dombos, DET dan Dombat

\begin{tabular}{|c|c|c|c|c|}
\hline \multirow{2}{*}{ Genotip } & \multicolumn{3}{|c|}{ Bangsa } & \multirow{2}{*}{ Rataan } \\
\hline & Dombos & DET & Dombat & \\
\hline \multicolumn{5}{|l|}{ Pre-albumin $(\mathrm{Pa})$} \\
\hline $\mathrm{Pa}^{1}$ & 0,375 & 0,575 & 0,350 & 0,433 \\
\hline$P a^{2}$ & 0,625 & 0,425 & 0,650 & 0,567 \\
\hline \multicolumn{5}{|l|}{ Albumin (Alb) } \\
\hline$A l b^{B}$ & 0,250 & 0,150 & 0,400 & 0,267 \\
\hline$A l b^{C}$ & 0,750 & 0,850 & 0,600 & 0,733 \\
\hline \multicolumn{5}{|c|}{ Ceruloplasmin (Cp) } \\
\hline$C p^{F}$ & 0,675 & 0,575 & 0,375 & 0,542 \\
\hline$C p^{s}$ & 0,325 & 0,425 & 0,625 & 0,458 \\
\hline \multicolumn{5}{|l|}{ Tranferrin $(T f)$} \\
\hline$T f^{A}$ & 0,575 & 0,150 & 0,225 & 0,317 \\
\hline$T f^{B}$ & 0,425 & 0,850 & 0,775 & 0,683 \\
\hline \multicolumn{5}{|l|}{ Post-tranferin $(P-t f)$} \\
\hline$P-t f^{F}$ & 0,875 & 0,575 & 0,500 & 0,650 \\
\hline$P-t f^{S}$ & 0,125 & 0,425 & 0,500 & 0,350 \\
\hline \multicolumn{5}{|l|}{ Amylase-I (Amy-I) } \\
\hline$A m y^{B}$ & 0,175 & 0,750 & 0,550 & 0,492 \\
\hline$A m y^{C}$ & 0,825 & 0,250 & 0,450 & 0,508 \\
\hline
\end{tabular}


menunjukkan frekuensi gen $T^{B}(0,683)$ lebih tinggi dibandingkan dengan frekuensi gen pada alel $T f^{A}(0,317)$. Penelitian Katsumata et al. (1981) menunjukkan bahwa pada kambing lokal Indonesia frekuensi gen Tf A lebih tinggi yaitu sebesar 0,525 dibandingkan frekuensi gen alel $T f^{\mathrm{B}}$ sebesar 0,475. Selanjutnya penelitian Tsunoda et al. (1999) menyebutkan bahwa frekuensi gen $T f$ A pada domba Mongolia sebesar 0,1046 sedangkan $T f^{B}$ sebesar 0,092.

Lokus post-transferrin

memiliki susunan pola pita yang berbeda antar individu. Hasil identifikasi lokus posttransferrin (P-tf) pada Dombos, DET dan Dombat dapat diketahui bahwa pita yang lebih cepat bergerak ke arah kutub positif (anoda) dinamakan alel $\mathrm{F}$ sedangkan yang bergerak lebih lambat dinamakan alel S. Frekuensi alel $P-t f^{S}$ pada Dombat dan DET relatif lebih tinggi dibandingkan Dombos. Pada Dombat frekuensi gen antara alel $P-t f^{\mathrm{F}}$ dan alel $P$-tf ${ }^{\mathrm{S}}$ memiliki jumlah yang sama yaitu 0,500. Namikawa et al. (1982) menjelaskan bahwa frekuensi alel $P-t f^{\mathrm{F}}$ pada Sapi Bali memiliki nilai yang lebih tinggi dibandingkan dengan $P$-tf $\mathrm{S}$. Sutopo et al. (2001) menyebutkan bahwa frekuensi gen alel S pada sapi Jawa lebih tinggi $(0,667)$ daripada alel F $(0,333)$.

Amylase-I memiliki berat molekul sebesar 110.000-120.000 dalton. Wyne et al. (1995) menyatakan bahwa lokus Am-I terletak setelah lokus cerruloplasmin (Cp), karena memiliki berat molekul lebih besar. Hasil identifikasi dan interprestasi gel elektroforesis amylase-I $(A m-I)$ pada Dombos, DET dan Dombat memiliki 2 alel yaitu $A m-I B$ dan $A m-I C$. Menurut Khana (1973), genotip $A m-I \quad C$ dan $A m-I \quad B$ ditemukan pada keledai. Pada Dombos, DET dan Dombat Am-I C lebih tinggi dibanding alel Am-I B. Hasil penelitian Bell (1992), plasma serum $\alpha 2$ globulin atau amylase-I memiliki alel Am-I $B$ lebih tinggi dibanding alel Am-I C. Hasil penelitian Chiapparino et al. (2006) menunjukkan alel $A m-I \quad B$ memiliki frekuensi gen lebih tinggi dibanding Am-I C pada kambing dan Domba Suffolk.

\section{Heterosigositas Domba}

Heterosigositas diperoleh dari hasil perhitungan frekuensi gen pada masingmasing lokus. Dinyatakan oleh Nei (1987) bahwa keragaman genetik dapat diukur melalui heterosigositas individual dan rataan heterosigositas $(\bar{H})$ pada lokus polimorfik maupun monomorfik. Hasil perhitungan heterosigositas individual dan rataan heterosigositas $(\bar{H})$ terlihat pada Tabel 2.

Menurut Simm (2000), semakin jauh hubungan kekerabatan antara kedua ternak maka semakin sedikit kesamaan gen-gen dan semakin besar tingkat heterosigositas. Nilai heterosigositas lokus pre-albumin $(\mathrm{Pa})$, albumin (Alb), ceruloplasmin (Cp), transferrin ( $T f$ ), post-transferrin (Ptf) dan amylase-I (Am-I) memiliki keragaman sesuai bangsa domba tersebut. Hal ini dapat dilihat dari penelitian domba dengan berbagai bangsa domba yang menunjukkan hasil rataan heterosigositas $(\vec{H})$ yang berbeda. Dijelaskan lebih lanjut oleh Tamura et al. (2011) bahwa nilai heterosigositas dapat digunakan untuk mengukur tingkat keragaman ternak dalam suatu populasi. Hasil penelitian Tsunoda et al. (1998) pada bangsa domba Vietnam menunjukkan bahwa hasil nilai rataan heterosigositas dari domba tersebut adalah sebesar 0,182. Penelitian yang sama dilakukan oleh Tsunoda et al. (1999) pada bangsa domba di Mongolia menunjukkan bahwa nilai rataan heterosigositas domba di daerah Kharkhorin (KH) dan Ulaanbaatar (UB) masing-masing sebesar 0,264 dan 0,246.

Pada penelitian Katsumata et al. (1981), nilai rataan heterosigositas pada kambing lokal Indonesia berkisar antara 0,031 sampai dengan 0,051, sedangkan pada kambing Mongolia (Nozawa et al., 1999) nilai rataan heterosigositas sebesar 0,044. Selanjutnya hasil penelitian Namikawa et al. (1982) menunjukkan bahwa nilai rataan heterosigositas dari 9 lokus yang dianalisis pada Sapi Peranakan Ongole, Madura dan Sapi Bali masing-masing sebesar: 0,318; 0,365 dan 0,135 . 
Tabel 2. Heterosigositas individual dan rataan heterosigositas enam lokus pada tiga bangsa domba di Jawa Tengah

\begin{tabular}{lccccccc}
\hline \multirow{2}{*}{ Bangsa Domba } & \multicolumn{7}{c}{$\mathrm{h}$} \\
\cline { 2 - 7 } & $\mathrm{Pa}$ & $\mathrm{Alb}$ & $\mathrm{Cp}$ & $\mathrm{Tf}$ & $P$-tf & $A m-I$ & $H$ \\
\hline Dombos & 0,469 & 0,375 & 0,439 & 0,489 & 0,219 & 0,289 & 0,380 \\
DET & 0,489 & 0,255 & 0,489 & 0,255 & 0,489 & 0,375 & 0,392 \\
Dombat & 0,455 & 0,480 & 0,469 & 0,349 & 0,500 & 0,495 & 0,454 \\
\hline
\end{tabular}

Tabel 3. Matrik jarak genetik biga bangsa domba di Jawa Tengah

\begin{tabular}{lccc}
\hline \multicolumn{1}{c}{ Bangsa } & Dombos & DET & Dombat \\
\hline Dombos & 0,0 & & \\
DET & $0,160 \pm 0,111$ & 0,0 & \\
Dombat & $0,157 \pm 0,022$ & $0,019 \pm 0,017$ & 0,0 \\
\hline
\end{tabular}

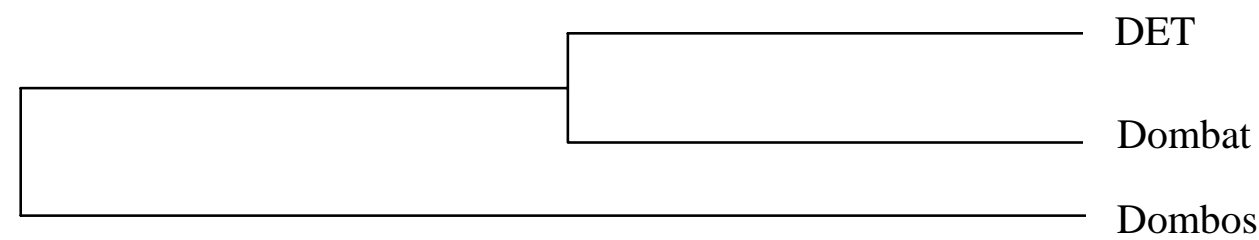

Gambar 2. Hubungan kekerabatan tiga bangsa domba di Jawa Tengah

\section{Jarak Genetik Bangsa Domba}

Jarak genetik merupakan tingkat perbedaan gen antara dua populasi, yang biasa dihitung berdasarkan fungsi dari frekuensi alel. Jarak genetik dapat digunakan dalam memperkirakan waktu terjadinya pemisahan antar populasi dan dapat juga digunakan dalam membangun pohon filogenetik (Nei dan Kumar, 2000). Jarak genetik antar bangsa domba dapat dilihat pada Tabel 3 dan hubungan kekerabatan antar bangsa domba pada Gambar 2 .

Terdapat hubungan kekerabatan lebih dekat antara DET dan Dombat sedangkan Dombos memiliki hubungan kekerabatan yang jauh. Proses migrasi dan seleksi serta persilangan yang tidak terkontrol menyebabkan jauhnya hubungan kekerabatan pada domba Wonosobo dibandingkan dengan domba lainnya. Persilangan antar ternak yang memiliki hubungan kekerabatan dekat (inbreeding) dapat meningkatkan gen-gen yang homosigot (memiliki genotip dua gen yang sama). Pohon filogenetik atau pohon evolusi adalah pohon yang menunjukkan hubungan evolusi antara berbagai spesies yang diyakini memiliki nenek moyang yang sama. Sebuah pohon filogenetik, setiap node dengan keturunan merupakan nenek moyang terbaru dari keturunan, dan panjang tepi dalam beberapa pohon sesuai dengan perkiraan waktu (Miller, 2009).

Makin jauh hubungan kekerabatan antara ketiga ternak, maka makin sedikit kesamaan gen-gen dan makin besar tingkat heterosigositas. Semakin dekat hubungan kekerabatan mengindikasikan adanya kesamaan yang tinggi pada lokus-lokus protein darah yang diamati, demikian pula sebaliknya. Semakin jauh hubungan kekerabatan mengindikasikan adanya keragaman atau variasi yang tinggi pada lokus-lokus protein darah yang diamati (Nei dan Kumar, 2000). 


\section{KESIMPULAN}

Lokus pre-albumin $(\mathrm{Pa})$, albumin $(A l b)$, ceruloplasmin $(C p)$, transferrin $(T f)$, post-transferrin $(P-t f)$ dan amylase-I $(A m-I)$, pada Dombos, DET dan Dombat bersifat polimorfik. DET dan Dombat memiliki hubungan genetik yang lebih dekat dibandingkan antara DET-Dombos dan Dombos-Dombat.

\section{DAFTAR PUSTAKA}

Andersson, E. L., B. Danell, and J. Rendel. 1993. Association of male fertility traits with blood groups and blood protein polymorphism in dairy cattle. Agriculture Scandinavica J. Anim. Sci. 43: 87-95.

Bell, T. R., S. S. Honn, W. Felipe, and F. W. Alderson. 1992. Amylase Enzymes at Elektrophoresis. Science Publisher, Finlandia.

Chiapparino, E., P. Donini, J. Reeves, R. Tuberosa, and D.M. O'Sullivan. 2006. Distribution of amylase-I haplotypes among european cultivated barleys. National Institute of Agricultural Botany. Huntingdom Road, Cambridge United Kingdom.

Dinas Peternakan Wonosobo. 2007. Profil Ternak Dombos Texel Kabupaten Wonosobo. Dinas Peternakan dan Perikanan Wonosobo, Wonosobo.

Hubbard, G. R. 1999. Ceruloplasmin loci at Tibet. J. Anim. Genet. 77 (1) : 167-169.

Johari, S., Sutopo., E. Kurnianto, and E. Hasviara. 2008. Polimorfisme protein darah ayam kedu.

J. Indon. Trop. Anim. Agric. 33 (4) : 313-317.

Katsumata, M., T. Amano, S. Suzuki, K. Nozawa, H. Martojo, I.K. Abdulgani, and H. Nadjib. 1981. Morphological characters and blood protein gene constitution of Indonesian goat. J. Rep. Soc. Res. Native Livestock. 2: 55-68.

Khana, N. D. 1973. Blood protein in the donkey. J. Anim. Genet. 80 (1): 5-7.

Miller, F. P. 2009. Molecular Phylogenetics. VDM Publishing House Ltd.

Namikawa, T., T. Amano, B. Pangestu and S. Natasasmita. 1982. Electrophoresis variation of blood protein and enzymes in Indonesia cattle and bantengs. The Research
Group of Overseas Scientific Survey: 3542.

Nei, M. 1987. Molecular Evolutionary Genetics. Colombia University Press, New York.

Nei, M. and S. Kumar. 2000. Molecular Evalution and Phylogenetics. Oxford University Press Inc, New York.

Nozawa K., T. Kenji, M. Yoshizane, T. Yuichi, Z. Tsesrejavyn, T. Horloojau, and T. Tsendsuren. 1981. Morphology and gene constitution of the Indonesian horses. In: The Origin and Phylogeny of Indonesia Native Livestock. Ed ke-2. Tokyo: The Research Group of Overseas Scientific Survey. Japan. pp. 9-30.

Nozawa, K., T. Kenji, M. Yoshizane, T. Yuichi, Z. Tsesrejavyn, T. Horloojau, and T. Tsendsuren. 1999. Gene-constitution of the native goat in Mongolia. J. Rep. Soc. Res. Native Livestock. 17: 83-94.

Ota, T. 1993. DISPAN Molecular Evalutionary Analisis MEGA. Institute of Molecular Evolutionary Genetics, Pennsylvania State University Park.

Simm, G. 2000. Genetic Improvement of Cattle and Sheep. Farming Press Miller Freeman Ltd., UK.

Smithies, O. 1955. Zone elektrophoresis in starch gels group variation in the serum protein of normal human adult. J. Biochem. 61: 629-641.

Sumantri, C., U.Fauzi dan A. Farajallah. 2007. The variation of microsatellite DNA among fat, medium and thin tail local sheeps. J. Prot. 14: 1-8.

Sutopo, K. Nomura, Y. Sugimoto, and T. Amano. 2001. Genetic relationships amongs Indonesian Native Cattle. J. Anim. Genet. 28: 3-11.

Tamura, K., D. Peterson, N. Peterson, G. Stecher, M. Nei, and S. Kumar. 2011. MEGA5: Molecular Evolutionary Genetics Analysis using Maximum Likelihood, Evolutionary Distance and Maximum Parsimony Methods. Molecular Biology and Evolution. Arizona State University, Arizona, USA.

Tsunoda, K., O. Hisota, A. Takashi, K. Kazuhito, N. Takao, Y. Takahiro, Y. Yoshio, X. Vo-tong, dan Ba Loc Chau. 1998. Morphological and genetic characteristics of sheep raised by the cham tribe in Vietnam. J. Rep. Soc. Res. Native Livestock. 17: 63-73. 
Tsunoda, K., K. Nozawa, M. Yoshizane, T. Yuichi, T. Tuya, B. Munkhtuya, T. Horloojav, T. Zanchic and B. Dashnyam. 1999. External morphological character and blood protein and non-protein polymorphisme of native sheep in Central Mongolia. J. Rep. Soc. Res. Native Livestock. 17: 73-82.

Warwick, E.J., J.M. Astuti, dan W. Hardjosoebroto. 1990. Pemuliaan Ternak. Gadjah Mada University Press, Yogyakarta.
Wyne, R.Z., H. Shelwyn, and T. Robert. 1990. Elektroforesis DNA: Allels of Blood protein. Wallingford, United Kingdom.

Winaya, A. 2010. Variasi Genetik dan Hubungan Filogenetik Populasi Sapi Lokal Indonesia Berdasarkan Penciri Molekuler DNA Mikrosatelit Kromosom Y dan Gen Cytochrome b. Disertasi. Institut Pertanian Bogor, Bogor. 